\title{
II. ARTÍ́CULOS
}

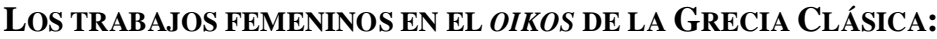 \\ LA MADRE, LA CUIDADORA, LA ADMINISTRADORA ${ }^{1}$}

\author{
Verónica Fernández García \\ Universidad de Oviedo \\ fernandezveronica@uniovi.es
}

Recibido: 02-02-09

Aceptado: 02-03-09

\section{Resumen}

La vida de las mujeres en la Grecia Clásica tenía lugar fundamentalmente en el seno del oikos, la casa griega. Y, especialmente, en la zona reservada a ellas, el gineceo. A menudo vivían allí las abuelas, las madres, las nietas,... junto con las sirvientas, las esclavas y los niños pequeños. En estas habitaciones hacían sus trabajos: cuidar de los hijos, de los bebés, hasta que cumplían siete años, cuidaban a los enfermos, asistían a los muertos, tejían e hilaban y administraban la casa y a los trabajadores domésticos. Así pasaban todo el tiempo, con un trabajo que dependía de los hombres, pero que era mucho más importante de lo que estos llegaron a conocer nunca.

\footnotetext{
${ }^{1}$ Este texto se inscribe dentro del proyecto de I+D del Ministerio de Educación y Ciencia que lleva por título "Maternidad y madres en las culturas grecorromana, oriental y cristiana primitiva. La construcción del paradigma de la feminidad en las sociedades antiguas del Mediterráneo", cuya directora es la doctora Rosa $\mathrm{M}^{\mathrm{a}}$ Cid López. La autora está disfrutando así mismo de una beca predoctoral de la Universidad de Oviedo con la siguiente referencia UNOV-06-BECBOC-9.

${ }^{2}$ Becaria Predoctoral de Investigación de la Universidad de Oviedo, adscrita al departamento de Historia, Área de Historia Antigua, Universidad de Oviedo.
} 
Palabras clave: Género, Mujeres, Trabajo doméstico, oikos, Maternidad, Tejer.

\begin{abstract}
Women's life in Ancient Greece mainly took place within oikos, the greek house, and especially in the area reserved to them, the gynaeceum. Grandmothers, mothers and granddaughters often lived there,... along with servants, slaves and little children. In these rooms they carried out their work: looking after children, babies, until the age of seven, caring the sick people, attending the dead people, weaving and spinning and managing the house and houseworkers. Thus they spent all the time fulfilling jobs that depended on men, but which were much more important than greek men ever thought.
\end{abstract}

Key words: Gender, Women, Housework, oikos, motherhood, to weave.

\title{
1. El espacio de socialización y trabajo de las mujeres en la Grecia Clásica: el oikos y el gineceo
}

“...¿Qué romano siente vergüenza de llevar a su esposa a un banquete?...Muy distinto es lo que acaece en Grecia, donde a la mujer no se admite en un banquete salvo que se celebre entre parientes, y no permanece sino en la parte más íntima de la casa, llamada "gineceo", en el que nadie puede penetrar excepto los parientes consanguíneos más próximos"

Nep., Prefacio, 6- $7^{3}$

“..Le mostré también el alojamiento de las mujeres, separado por una puerta con cerrojo del de los hombres, para evitar que se saque algo de dentro que no convenga ni puedan procrear hijos los esclavos sin nuestro consentimiento..." Xen., oik. (oec.), IX, 5

\footnotetext{
${ }^{3}$ Cornelio Nepote fue un biógrafo e historiador romano que vivió en el siglo I a.C. y dedicó su vida a escribir biografías de personajes célebres masculinos.
} 
La mayor parte de la vida de las mujeres griegas del mundo antiguo transcurría entre los muros de un hogar que, ni tan siquiera, era el suyo propio en ninguno de los estadios de su vida. Y es que estaban excluidas de la vida pública, salvo raras excepciones como es el caso de las mujeres espartanas ${ }^{4}$ y poco más, por lo cual vivían y morían en el seno del oikos $^{5}$ (la casa), primero el de su padre y después el de su suegro o su esposo, siempre pues al amparo de un varón que ejercía su poder, su dominio y su control sobre ellas ${ }^{6}$.

La historia de Grecia fue muy amplia, y aunque siempre se ha tomado el modelo ateniense como paradigma de dicha cultura, eso supone restringir mucho el campo de estudio, puesto que las condiciones no fueron las mismas en el mundo colonial que en el viejo mundo griego, en Oriente que en Occidente, en Esparta que en Atenas, en el campo que en la ciudad, entre los ricos que entre los pobres,... Pero lo que sí podemos afirmar que ha sido una constante en estos estados donde la soberanía residía en la colectividad de los que formaban la ciudad, los ciudadanos ${ }^{7}$, es el hecho de que las mujeres eran consideradas eternas menores de edad, permaneciendo al margen de la comunidad, y siendo necesarias solamente para asegurar la reproducción, pero sin ningún tipo de derecho ${ }^{8}$. Por eso, en este trabajo vamos a estudiarlas como un todo, porque a pensar de los matices, y sin detenernos pues en las espartanas, todas ellas

\footnotetext{
${ }^{4}$ Cuya peculiar circunstancia, y a pesar de los escasos y contradictorios testimonios que han perdurado sobre su situación concreta, parecen evidenciar que eran liberadas tanto del cuidado del oikos como de la educación de los hijos, aunque siempre a favor del cuidado atlético que les dotara de unas condiciones físicas propicias para el ejercicio, al fin y al cabo, de la que es la labor clásica de todas las mujeres griegas, la maternidad (Mossé, 2001: 91-101).

${ }^{5}$ El oikos es la unidad principal de producción y consumo (Mirón Pérez, 2007: 272).

${ }^{6} \mathrm{Y}$ respecto a esta reclusión hay que señalar que mientras que las mujeres casadas raras veces cruzaban el umbral de la puerta de su hogar, eran las muchachas jóvenes las que tenían aún mayores restricciones, puesto que penas salían ni al patio exterior de las mismas, ya que debían permanecer alejadas de la mirada masculina incluso de los miembros de su propia familia (Flacelière, 1989: 78).

${ }^{7}$ Merece la pena no olvidar que en Atenas nadie se veía apartado de ella a causa de su pobreza o del ejercicio de una profesión desprestigiada.

${ }^{8}$ Ver C. Mossé (2001: 46).
} 
gozaban sin duda de una misma condición dentro de su hogar, la de eternos seres dependientes y trabajadoras cuasi serviles ${ }^{9}$.

En cuanto al espacio doméstico, los restos arqueológicos que encontramos en algunos asentamientos helenos anteriores al siglo IV a.C. parecen confirmar que las viviendas eran de un tamaño moderado y se distribuían en torno a un patio central, que era invisible desde la calle, sobre el que se abrían la mayor parte de sus habitaciones ${ }^{10}$. Parece constatarse que la austeridad en estas edificaciones era una constante frente al esplendor de los grandes edificios públicos, puesto que el espacio intramuros, aquel que estaba reservado exclusivamente a los varones de la casa, trataba de escapar de las miradas de espectadores ajenos.

Pues bien, el sometimiento femenino dentro del hogar era tal, que solamente tenían una parcela dentro del mismo, el gineceo, unas habitaciones propias que se encontraban situadas en la parte trasera de la casa, lo más lejos posible de la calle ${ }^{11}$, y que estaban claramente diferenciadas de la parte masculina o andron. Por lo tanto, ni tan siquiera en el interior de la casa, del espacio designado para las mujeres, podían moverse a su voluntad. El gineceo no estaba cerrado con ningún tipo de llave, pero como señala Robert Flacelière, bastaba la costumbre para retener a las mujeres en casa $^{12}$, es decir, no hay peor condena que la impuesta por el derecho consuetudinario, por el paso de los siglos, de lo que sin duda son claros ejemplos las mujeres de la Grecia Clásica.

\footnotetext{
${ }^{9}$ Puesto que en Grecia, incluso en las casas de los ciudadanos más acomodados, el trabajo de ir a buscar el agua y preparar la comida lo hacían las esclavas, pero se esperaba de la mujer de la casa, incluso entre la aristocracia que tomara parte en las tareas domésticas más respetables como el hilado o el tejido (Jenkins, 1998: 19), así como era la encargada de organizar toda la servidumbre y llevar el control del hogar (Mossé, 2001: 34-38).

${ }^{10} \mathrm{El}$ autor nos habla en esencia de la ciudad de Olynthos, al norte de Grecia, que será destruida en el año 348 a.C. por los Macedonios (Jenkins, 1998: 12), aunque nos informa también de que en el caso de Atenas sin duda no había diferencias al calor de las pocas casas que han sido excavadas en el interior de los muros de la ciudad.

${ }^{11}$ Ver I. Jenkins (1998: 16).

${ }^{12}$ Ver R. Flacelière (1989: 90).
} 
Y se hace necesario aclarar en este punto que entendemos por mujer ateniense a la hija o mujer de ciudadano, y por tanto madre de ciudadano, dado que aunque el término de ciudadana existía hay que tener cuidado con su empleo, porque poco tiene que ver con la concepción de ciudadanía (que supone el ejercicio de una función política, de una participación en la Asamblea y en los tribunales), algo de lo que quedaban completamente excluidas las mujeres, tal cual lo eran de la mayor parte de las manifestaciones cívicas, con excepción de alguna ceremonia religiosa ${ }^{13}$.

La vida de la mujer en Grecia sólo tenía un punto de inflexión, un momento crucial que marcaba el inicio de su función social, del desempeño de su labor para con la ciudad, el convertirse en esposa ${ }^{14}$, de un ciudadano preferentemente. Lo cual lleva al fin último de la mujer, a la segunda de sus principales ocupaciones domésticas, ser madre de hijos que cuidasen de sus padres en la vejez y que, tras la muerte, cumpliesen con los ritos necesarios del culto familiar. Este momento suponía el abandono del oikos paterno, y la entrada en la del marido, donde su vida tampoco iba a sufrir un cambio sustancial, dado que las labores que desempeñaba en uno van a perpetuarse en su nuevo ámbito familiar.

En este orden de cosas poco difiere la situación de las solteras, con la de las casadas, puesto que ambas estaban recluidas en ese "espacio femenino" interior, siempre al amparo de un varón. Lo que sí solía ser distinta era la situación de las mujeres más humildes y las pudientes, puesto que las primeras disponían de una vivienda más reducida, pero contaban con la posibilidad de salir de casa con más facilidad, debido a que en su mayoría estaban obligadas a trabajar fuera para ayudar en la economía familiar, o a salir para comprar. Mientras que las clases medias y altas eran

\footnotetext{
${ }^{13}$ Ver C. Mossé (2001: 58).

${ }^{14}$ El matrimonio constituye, por tanto, el fundamento mismo de la situación de la mujer (Mossé, 2001: 58); por tanto, la vida de toda mujer griega, hija o esposa de ciudadano, se dividía en dos situaciones diferentes, antes y después del matrimonio (Mirón Pérez, 2002: 56-57); un tránsito que según Hesiodo debía tener lugar cuando la novia contara con dieciséis años y el novio con treinta, y parece que contrario a lo que sucederá en Roma, no se daba en matrimonio a muchachas impúberes (Flacelière, 1989: 82); lo que parece un hecho constatado es la diferencia de edad entre ambos esposos.
} 
más estrictas en cuanto a las salidas, pero disponían de gineceos más amplios y de grandes patios interiores donde podían tomar el aire protegidas de las miradas del exterior $^{15}$. Por consiguiente, las atenienses más pobres quizá vieran involuntariamente aumentado ese espacio, aunque sólo en los momentos descritos.

Hay abierto en torno a todo esto un debate que trataría de desentrañar si la mujer era considerada como una parte del oikos, como "algo" más dentro de la casa, dado que todas las viviendas contaban con un número de mujeres variable, pero siempre había alguna representante femenina en ella. Según Claudine Leduc en la "casa homérica" ese espacio doméstico englobaría: primero la casa, en segundo lugar su contenido, las cosas poseídas, así como la parcela de tierra y, por último, el ganado ${ }^{16}$. Así, tanto la mujer como los hijos quedarían incluidos en ese todo unitario que es la casa y cuyo rector y organizador es ese señor del oikos, que le daría nombre, a la vez que mantendría unidos a los elementos que conforman ese grupo reproductor.

Los primeros estadios de la vida de una ateniense transcurrían entre los muros de ese gineceo, donde aprendían de las mujeres de su hogar (abuelas, madres, hermanas o criadas, en las familias más acomodadas) las actividades que eran deseables para una joven y de las que hablaremos más adelante: la cocina, el tratamiento de la lana, el tejido; y quizá, de manera muy rudimentaria y no en todos los casos, nociones de lectura, cálculo y música.

Es, curiosamente y de forma casi exclusiva, para el transcurso de algunas de las fiestas religiosas ${ }^{17}$, destinadas por otro lado a perpetuar su función como mujeres $\left(\right.$ Panateneas ${ }^{18}$, las fiestas de Dioniso, los Misterios de Eleusis,..${ }^{19}$ ), cuando abandonaban el gineceo tan sólo por unos días al año. Un margen de "libertad" controlada que no era

\footnotetext{
${ }^{15}$ Ver R. Flacelière (1989: 90).

16 Ver C. Leduc (1991: 256). C. Mossé hace una equivalencia entre el término oikos y el de dominio o propiedad, puesto que no sólo hace alusión a la hacienda, sino también al grupo humano estructurado de forma más o menos compleja que habita en él (Mossé, 2001: 15).

${ }^{17}$ Ver M. D. Mirón Pérez (2001: 26-29).

${ }^{18}$ Sobre la fiesta de las Panateneas ver M.E. De La Nuez Pérez (2004).

${ }^{19}$ Sobre las fiestas y la vida religiosa femenina, tanto pública como privada, en Grecia ver a L. Bruit Zaidman (1991: 372-419); y E. Almirall Arnal (2002: 113-133).
} 
tan real como aparentaba, puesto que no era una forma de concederles unos días de asueto, sino una consagración de sus funciones; el caso más claro es el de la procesión de las Panateneas, donde confeccionaban ese manto para la diosa Atenea; es decir, cultivaban la función más deseable para ellas, el trabajo de la lana, el mismo que realizaban en el oikos.

No obstante, y a pesar de que en una economía fundamentalmente agraria como es la griega clásica es cierto que las fuentes de riqueza primarias se hallaban fuera de ese oikos - un espacio que sin ninguna duda era competencia de los varones - había otras actividades que necesariamente tenían que darse dentro de él, y éstas labores sí eran eminentemente femeninas, en ellas se centrará este trabajo.

\section{El gran cometido de las mujeres: la maternidad y el cuidado de los hijos del esposo}

“...a la mujer, al darle un cuerpo menos capaz para estas fatigas, la divinidad le encomendó, me parece a mí, las faenas de dentro. Y sabiendo que había inculcado en la mujer y le había encargado la crianza de los niños recién nacidos, también le adjudicó en el reparto un mayor cariño hacia los recién nacidos que al hombre..."

Xen., oik. (oec.), VII, 23-25

Hemos hablado pues de las esposas y de su función, se hace necesario ahora hablar de otra ocupación, puesto que la doncella que se casaba dejaba de serlo, pero no era considerada por entero como mujer hasta que no hubiera dado a luz a su primer hijo, o en su defecto hija promesa de futuras alianzas ${ }^{20}$. Tal es así que la propia denominación

\footnotetext{
${ }^{20}$ Ver L. Bruit Zaidman (1991: 405). “...Los papeles asignados a cada sexo serán, básicamente, para los hombres, la dirección de la ciudad; para las mujeres, su reproducción...” (Mirón Pérez, 2001: 6).
} 
que se hace de la mujer cambia cuando se convierte en madre: la niña parthenoi pasa a ser una nymphé cuando se casa, pero no se convierte en gyné hasta que no ha sido madre $^{21}$. Con lo cual se ve una evolución en su condición como mujer en la sociedad a través del ejercicio de su maternidad.

Esta era la gran función para la que las mujeres eran preparadas desde su más tierna infancia, el verdadero papel que jugaban para con la $\operatorname{sociedad}^{22}$, aquel que les convertía en sujetos que permitían garantizar la vida y la estabilidad de los estados, la maternidad legítima. Era el servicio de las mujeres a la ciudad, darle y criar nuevos ciudadanos $^{23}$. Un reconocimiento que no obstante será un arma de doble filo, puesto que este discurso político acerca de la mujer-madre conllevará un mayor control de la esposa legítima, el cual, eso sí, era "compensado" con un puesto de honor en la casa al que ninguna otra mujer podrá acceder y con la protección de los hijos legítimos frente a los bastardos que el esposo habría tenido con las otras mujeres ${ }^{24}$.

Empezaremos por afirmar que los matrimonios griegos no solían ser muy fecundos por dos razones: muchas veces el marido satisfacía su apetito sexual con las "otras mujeres" que hemos mencionado ${ }^{25}$; así como no se deseaba tener muchas bocas

\footnotetext{
${ }^{21}$ Ver R. M. Olvera (2005: 8-9).

${ }^{22}$ Ver M.D. Molas Font (2002: 173), quien al hablar de las mujeres de las obras homéricas afirma que "...las féminas sólo alumbran: ellas paren a los hijos y a las hijas, pero la fuerza generadora que aporta la simiente es masculina...”, tal es así que en dichos poemas los filólogos y filólogas que en el análisis de los verbos que se emplean para describir la concepción de los vástagos traducen por "parir" cuando se trata de las mujeres, y por "engendrar" cuando se refiere a los hombres; ver esta idea aristotélica desarrollada en (Madrid, 1999: 306-327). La producción de hijos legítimos era la aportación común de marido y mujer al oikos (Mirón Pérez, 2007: 276).

${ }^{23}$ Como ya reflejara Medea, en una idea que marca el ideal espartano, la guerra es al varón lo que el parto a la mujer (Durán López, 1996: 47); una idea ampliamente abordada por N. Loraux (2004 a); ver en A. Iriarte Goñi (1996: 82-83) una equiparación entre maternidad y función guerrera que según esta autora no sólo se daba entre las espartanas, sino que el mismo ideal era el que imperaba en Atenas. Era la contribución fundamental de las mujeres a la polis (Mirón Pérez, 2007: 276). La sociedad griega manifiesta una constante preocupación por mantener contra viento y marea el potencial militar de la comunidad, por lo que la maternidad será la forma y la contribución femenina para reemplazar los muertos (Brulé, 2001: 200).

${ }^{24}$ Ver A. Iriarte Goñi (1996: 78).

${ }^{25}$ Aquellas de las que nos hablara Demóstenes (Demosth. Discursos Privados, Contra Neera, 122).
} 
que alimentar, cosa nada fácil en esta sociedad, y lo ideal era tener un único hijo varón que salvaguardara el patrimonio y la memoria familiar ${ }^{26}$.

El aborto no estaba prohibido en Grecia, pero ante todo primaba la salvaguarda de los derechos del padre, por lo que las mujeres no podían jamás interrumpir el embarazo sin el consentimiento de su marido, al igual que no podía hacerlo la esclava sin el permiso de su amo, lo cual nos da una idea de la intervención femenina en el embarazo y su poder sobre su propio cuerpo. No se reconoce ni la autoridad materna, ni tan siquiera el derecho a la vida del niño que está por nacer, sino de nuevo los intereses del varón que tiene derecho sobre ambos ${ }^{27}$.

El momento del alumbramiento estaba cargado de connotaciones negativas, puesto que se creía un estadio en el que se entraba en contacto con la sangre femenina, con lo impuro, así como con numerosos daimones que acompañaban este momento. Se creía que el cuerpo femenino estaba inacabado, igual que el de un niño, por ello carecía del semen masculino. Esto las hacía más pequeñas, más débiles, más frías, y por ello más propensas a una muerte prematura. La mujer era en sí misma un defecto ${ }^{28}$.

Y es precisamente esa falta de calor vital la que entraña la debilidad de su metabolismo, de la cocción, según Aristóteles (La Generación de los animales 738 a$b^{29}$ ), lo que explica al mismo tiempo el ciclo menstrual, así la sangre que pierde en estos momentos sería signo de su inferioridad e impureza (el equivalente al esperma masculino es esta sangre, aunque ésta no ha sido cocida). De lo que deriva que el principio generador es siempre el masculino, el padre, mientras la madre sólo suministra esta materia inerte; el varón es la vida, la mujer el cuerpo). De tal modo, que de una sola vez se ha justificado la inferioridad femenina con respecto al varón, y la pasividad de la mujer en la concepción de los hijos, y, por tanto, su no-vinculación a los mismos.

\footnotetext{
${ }^{26}$ Menandro describe esta necesidad de tener pocos hijos con las siguientes palabras: “...No hay nadie más desgraciado que un padre, sino otro padre que tenga más hijos que él...” (Flacelière, 1989: 102).

${ }^{27}$ Era común la exposición de las niñas al nacer, a veces con técnicas tan crueles como era darles menos comida, menos cuidados u obligarla a trabajos forzosos precoces (Brulé, 2001: 205).

${ }^{28}$ Ver G. Sissa (1991: 94).

${ }^{29}$ Citado en G. Sissa (1991: 96).
} 
Antes del nacimiento, y a causa de esa impureza, la casa era pintada con pez, pues no sólo quedaba impura la madre, sino todas las personas en contacto con ella; es decir, todas las gentes que habitaban en la casa, así como el hogar mismo.

En cuanto el nuevo miembro nacía, se colocaba sobre la puerta una rama de olivo si era varón, o una banda de lana si era niña. Es decir, la victoria para el hombre maduro, las labores domésticas para la futura mujer. Y, desde entonces, la madre era quien se encargaba de asegurar su supervivencia, su crecimiento y la educación de sus primeros años ${ }^{30}$.

Se consideraba, incluso, que la formación biológica de un niño y una niña era distinta, por lo que existía la idea de que la debilidad del sexo femenino requería un periodo de cuarenta y dos días para la formación del feto de las hembras, mientras que treinta días eran suficientes para el de los varones; por consiguiente, las etapas clave en la vida de un ciudadano ateniense y de una mujer hija de un ciudadano estaban marcadas por ritos de naturaleza bien distinta ${ }^{31}$. Ya desde su nacimiento eran tratados y vistos conforme a los roles de género que estaban destinados a encarnar.

Respecto al sexo del bebé, sería curioso analizar la interpretación de los filósofos. El ideal era que los hijos fuesen varones y se parecieran al padre; por lo que la explicación al nacimiento de las mujeres era una consecuencia de la excesiva juventud o vejez, o tal vez alguna malformación de algún tipo, del semen masculino. Es decir, desde la misma concepción del feto, las mujeres quedaban estigmatizadas como materia deforme, producida por una alteridad de la aportación sexual del padre. Lo mismo ocurriría cuando nacía un varón y se parecía a su madre, algo que manifestaba una cierta inferioridad de los hombres. Un tema muy interesante, pues desde el nacimiento la hembra queda diferenciada del macho ${ }^{32}$.

\footnotetext{
${ }^{30}$ Ver en M. D. Mirón Pérez (2007: 276).

${ }^{31}$ Ver en M. D. Molas Font (2003: 120).

${ }^{32}$ Ver G. Sissa (1991: 104-106).
} 
El quinto o el séptimo día después del nacimiento se celebraba la fiesta de las Amfidromias, con un claro sentido familiar ${ }^{33}$. Y consistía en la purificación de la madre, de las personas que habían intervenido en el parto, así como se presentaba al niño a su grupo social. Es decir, alrededor de una semana después del nacimiento se consideraba que ya no era peligroso el contacto con la madre y el hijo. El décimo día, los miembros de la familia se reunían de nuevo para realizar un sacrifico y un banquete en honor del nuevo miembro de la familia, en el transcurso de los cuales se le ponían nombre definitivamente, momento que sin duda marca el punto de inflexión en que el recién llegado era considerado una persona. Ese mismo día, se estimaba que la madre ya estaba purificada, y era entonces cuando podía incorporarse a sus quehaceres domésticos.

En las familias más humildes, las madres ocuparían a partir de ese momento la empresa del cuidado y la crianza de los hijos. Pero incluso esta ocupación les era negada en muchas ocasiones, puesto que en las familias más pudientes eran contratadas nodrizas que cuidaban y amamantaban al bebé, quizá en un intento de que madre e hijo tuvieran la menor relación posible ${ }^{34}$.

Pero aún así, la madre era muy importante en estos primeros estadios. Ellas mecían y cantaban a sus hijos en sus cunas de mimbre o en artesas de madera, mientras les cantaban nanas. Ella le enseñaba sus primeras nociones de la vida: a leer, a escribir ( si es que ellas sabían hacerlo), cálculo,... y quizá les iniciaran en la mitología y las leyendas nacionales, transmitiéndoles a su vez lo que ellas mismas habían aprendido en

\footnotetext{
${ }^{33}$ Ver R. Flacelière (1989: 104).

${ }^{34}$ Ver R. Flacelière (1989: 114-115); algunas pinturas muestran a la nodriza llevando desnudo al pequeño, al que seguramente acaban de limpiar, a su madre que espera sentada para darle el pecho. Sobre el papel que desempeñaban estas mujeres y su plasmación a través de la producción literaria ver I. Calero Secall (1999).
} 
su infancia, preparando quizá para la posterior comprensión de los poemas homéricos y hesiódicos a sus hijos ${ }^{35}$.

No obstante, el padre gozaba de una libertad casi completa para educar el mismo o permitir que otros educaran a sus hijos como considerara oportuno hasta los dieciocho años, edad en la que el adolescente se convertía en ciudadano e iniciaba su vida cívica mediante el aprendizaje del oficio de las armas. Aunque parece que el ciudadano estaba tan ocupado en sus asuntos fuera de la casa que durante este largo periodo de al menos siete años no se interesaba mucho por el pequeño ${ }^{36}$.

Hay numerosas pinturas en los vasos griegos que nos representan a niños jugando en el gineceo, con amuletos colgados del cuello que les protegían de los males y las enfermedades, sin duda colocados por sus madres o por sus cuidadoras con el consentimiento de éstas. En ellos, los niños son representados casi desnudos, en cambio, las niñas están cubiertas con vestidos bastante primarios ${ }^{37}$.

Si el hijo era un varón, y una vez comenzada su educación en la escuela, la madre pronto se veía incapaz de ayudarle, puesto que ella no había sido educada a tal efecto. En el mundo antiguo, no obstante, la escolarización se daba sólo entre los hijos de las familias más acomodadas, quienes contrataban para los niños varones unos pedagogos a sueldo, o incluso a alguno de los esclavos de la casa, y la instrucción solía comenzar a los siete años ${ }^{38}$ (primero con los grammatistes que enseñaban los rudimentos de la lectura, luego los kitharistes con la música, y luego los paidotribes que inculcaban la formación física; luego en última instancia en la adolescencia los jóvenes

\footnotetext{
${ }^{35}$ Ellas eran las depositarias de la tradición, así como eran grandes conocedoras de un sinnúmero de saberes tradicionales (Durán López, 1996: 62). Esta autora nos ilustra sobre las pinturas de la cerámica griega, señalando que mientras los hombres siempre aparecen escribiendo, las mujeres son las que ocupan la mayor parte de las escenas de lectura, así que lo que sorprende es el escaso número de escritoras que hubo en esta sociedad si estos datos son tan reales como lo percibimos gráficamente.

${ }^{36}$ Ver R. Flacelière (1989: 115); e I. Jenkins (1998: 32).

${ }^{37}$ Ver R. Flacelière (1989: 118).

${ }^{38}$ A partir de esa edad su educación pasaba a ser radicalmente diferente con respecto a la de las niñas, pues vendrá marcada por un componente intelectual y militar M. D. Mirón Pérez (2001: 35)
} 
podían recibir una educación más estricta en alguno de los campos de la filosofía ${ }^{39}$ ), hasta ese momento es probable, pues, que la formación la aportaran las mujeres de la $\operatorname{casa}^{40}$.

Si se trataba de una niña, desde muy temprano era instruida en las labores “propias de su género", para que volviera a repetir el mismo rol encarnado en su madre. En el caso de los niños, estos pasaban pronto a los cuidados del padre, o del tutor legal si éste había fallecido, sin duda cualquier relación con la madre era vista como poco deseable, como una feminización, algo poco estimado (ejemplificado magistralmente en el mito de Hefesto y Hera, donde la excesiva participación de la madre da lugar a un ser cojo y deforme $\left.{ }^{41}\right)$.

La niña griega nunca iba a la escuela como sí lo hacían sus hermanos, al menos hasta época helenística. En casa aprendía con las mujeres lo que había que saber, lo cual nos puede crear una idea de un saber un tanto rudimentario, algo que se refuerza si pensamos en la temprana edad en que contraía matrimonio ${ }^{42}$. Pero nos centraremos ahora en abordar cuales eran sus trabajos para ver si esto se correspondía con la realidad.

\section{El cuidado de los enfermos: la mujer y la asistencia a enfermos y desahuciados}

“...Si se pone enfermo uno de los esclavos, tienes que procurar por todos los medios que se cure..."

Xen., oik. (oec.), VII, 36-37

\footnotetext{
${ }^{39}$ Sobre las condiciones generales de la educación de los niños varones en Grecia consultar R. Flacelière (1989: 119-139).

${ }^{40}$ Ver I. Jenkins (1998: 35-36).

${ }^{41}$ Acerca de la concepción de Hefesto, ver Hes. (Theog., 928-933).

${ }^{42}$ Ver M. A. Durán López (1996: 62).
} 
Por tanto, la maternidad no era el único trabajo femenino en relación a la atención de las personas que conformaban el oikos, sino que hay otro ámbito, también relacionado con la contaminación por asociación como lo estaba todo el ceremonial del parto, que era igualmente peligroso y que, de esta forma, se encargaba a las mujeres. Las mismas que intervienen en el nacimiento lo hacen en la muerte ${ }^{43}$, de nuevo pues en su función de cuidadoras. Y es que sólo en casos graves se recurría al médico, y eran las mujeres de la casa las que se dedicaban a las tareas de asistencia y enfermería ${ }^{44}$.

$\mathrm{Su}$ "salvajismo", su no inclusión en la ciudadanía ni en el ejercicio de la misma, las acerca a estos espacios de misterio (nacimiento y muerte), de la nada al todo $\mathrm{y}$ viceversa ${ }^{45}$; a la vez que las aleja de los hombres, marcando su estereotipo de alteridad con respecto a los varones. Para ellas, este ámbito no era pues deshonroso, como sí lo era para ellos, pues por su propia "naturaleza", es decir, por su función biológica, ellas estaban preparadas para el contacto con lo impuro. No obstante, su participación en relación con la muerte estaba también muy reglamentada, tal es así que la ley de Solón determinaba que solamente tendrían derecho a entrar en la casa del fallecido, o a seguir la comitiva, las mujeres cuyo parentesco era más próximo que el de hijos de primos ${ }^{46}$, mientras son admitidos todos los hombres que se presenten en la casa.

\footnotetext{
${ }^{43}$ Como señala L. Bruit Zaidman: "Dueñas del nacimiento, y, por ende, en contacto con las fuerzas más secretas, portadoras de la impureza a causa de esa misma familiaridad, las mujeres desempeñan también un papel específico en los rituales que acompañan a la muerte..." (Bruit Zaidman, 1991: 408).

${ }^{44}$ Ver M. D. Mirón Pérez (2007: 276).

${ }^{45}$ Mujeres parteras eran quienes asistían en el nacimiento, y eran también aquellas que se encargaban de lavar el cuerpo del difunto (Olvera, 2005: 9), puesto que la impureza no afectaba a quienes por definición eran seres impuros, como son las mujeres.

${ }^{46}$ Ver R. Flacelière (1989: 106).
} 
Había todo un ceremonial perfectamente orquestado en relación a la muerte ${ }^{47}$, y en él podemos ver de forma muy nítida ese papel femenino a él asociado ${ }^{48}$. Rituales en los que las mujeres ocupaban esas funciones relacionadas con la algarabía y el “desorden”, frente al acompañamiento, y quizá la vigilancia, de los varones de la familia del difunto. Tal es así, que muchas veces eran contratadas mujeres a sueldo para cantar el treno, las denominadas plañideras, para que no fueran las dignas mujeres de las familias griegas pudientes las que llevarán la dura carga de "alterar" su ánimo en señal de duelo por el difunto ${ }^{49}$.

Este trámite llevaba parejo una serie de pasos, el primero es el del lavado del cuerpo, que era realizado por las parientas del fallecido mediante el uso de agua, preferiblemente marina. Una ceremonia poco conocida, que continuaba con el ungimiento y vestido del cuerpo, para eliminar del cadáver la supuesta contaminación que le producía el contacto con la muerte. Si la fallecida era una muchacha joven, aún sin desposar, era ataviada con el traje de novia o el velo, lo que le facilitaba el cumplimiento simbólico del matrimonio para llevar a cabo esa función que venimos

\footnotetext{
${ }^{47} \mathrm{Y}$ es que el primer deber de los hijos era velar por los padres cuando fueran ancianos y procurarles todo aquello que precisaran, siendo lo más importante el enterrarles según los ritos en el momento de la sepultura, una función que en Atenas era tan trascendental que se incumplimiento suponía una infracción de una ley de Solón y su consiguiente multa (Flacelière, 1989: 105). Estos rituales podían ser caros o sencillos, pero su finalidad e importancia era la misma, asegurar al alma del difunto su tránsito a la otra vida, y no tenerlos era una desgracia mayor que la muerte misma (Jenkins, 1998: 40).

${ }^{48}$ Como señala M. D. Molas Font: Llorar, gritar, rasgarse las vestiduras, lacerarse el cuerpo, lamentarse, etc. son manifestaciones externas de dolor dedicadas a los difuntos y difuntas, no exentas de significado social, que las comunidades griegas antiguas expresaron en forma de ordenados rituales ..." (Molas Font, 2003: 102).

49 Pero parece que aún estas mujeres eran utilizadas por las familias en un sentido más de ostentación, dado que los funerales eran una de las fórmulas de demostración pública de la condición de los diferentes clanes, y llegó a desatarse una fuerte rivalidad entre las diferentes familias que competían entre sí en la muestra de sus riquezas, hasta el punto de tener que hacerse necesaria la prohibición de los lujosos trajes que estas plañideras profesionales llevaban (Jenkins, 1998: 43).
} 
comentando y que era la más importante de la vida de cualquier griega, la de esposa ${ }^{50}$. Quizá esto se debiera a que como el paso al estatus de mujer de un ciudadano era el único rito de paso de una mujer dentro de su sociedad, era una forma de considerar que estas mujeres no pudieron llegar a ese momento, una manera de reconocerles un papel dentro de la sociedad, a pesar de que no llegaron a culminarlo.

Después de esto venía la próthesis, es decir, la deposición del cadáver en un sarcófago o encima de un lecho. Esta fase tenía diferente duración dependiendo de la honorabilidad del difunto, pero lo realmente importante es que el lamento funerario recitado por las mujeres era la parte esencial de esta exposición del cadáver, y aquí es donde empieza su labor la plañidera.

Alrededor del cadáver parece que se juntaban las mujeres de su familia con sombrillas y abanicos para protegerlo del sol y las moscas; mientras otras, también al lado de la cama, se echaban cenizas en los cabellos, se desgarraban las mejillas, se golpeaban el pecho, la cabeza,... lanzando esos lamentos funerarios (ololyge $e^{5 l}$ ), que parece que la ley trataba de reprimir.

Mientras se daba esta ceremonia, delante de la casa se colocaba un vaso (ardanion) lleno de agua lustral que se había ido a buscar a casa de los vecinos, pues la de la propia se consideraba contaminada, para que todo el que saliera del hogar se rociara con esa agua, así como los transeúntes vieran al paso por la casa que dentro había un fallecido.

El tercer paso era la ekphorá, el traslado del difunto o difunta a la tumba. Al frente de la comitiva iría una mujer que llevaría un vaso de libaciones, tras ella los

\footnotetext{
${ }^{50}$ Del mismo modo que en algunas ocasiones se colocaba un loutrophoros sobre la tumba de aquellos que murieron antes del matrimonio, puesto que la creencia era que el alma de quienes habían muerto sin contraer nupcias permanecía en un limbo poco deseable; pero además en el caso de las mujeres éstas pobres "jovencitas" no habían podido desempeñar su rol social como esposas y madres, mientras los jóvenes varones no habían logrado engendrar hijos ni proporcionar un hogar a sus ancianos padres (Jenkins, 1998: 38). Por ello la poesía y los epitafios dedicados a los jóvenes que murieron pronto, antes de poder contraer matrimonio, normalmente hacen referencia de forma simbólica a un matrimonio en el más allá (Jenkins, 1998: 40).

${ }^{51}$ Ver R. Flacelière (1989: 106).
} 
hombres, y por último los parientes femeninos más cercanos al fallecido; cerrarían el cortejo los tañedores de oboe.

Se inhumaba o cremaba al difunto fuera de las murallas de la ciudad, se le ofrecían libaciones. Se levantaban estelas cerca del enterramiento o sobre él para conmemorarlo. Y a este respecto es llamativo que en Esparta sólo las madres fallecidas en el parto y los guerreros caídos en combate eran dignos de ella, lo cual supone que se equiparaban las funciones de unos y otros, para las mujeres el dar a luz y para los hombres la defensa de la polis ${ }^{52}$.

Ya en el hogar, se celebraban largos rituales de purificación, puesto que las impurezas provocadas por el contacto con la muerte eran las peores de todas; así que eran encargadas a las parientes femeninas. Todos los familiares se lavarían el cuerpo y luego tendría lugar una comida fúnebre. Ya al día siguiente se procedería a purificar la casa con agua del mar y un hisopo. Y al tercer, al noveno y al trigésimo día después, tal como en los aniversarios, se repetían los banquetes, ese es el comienzo del culto a los muertos.

A partir de entonces, la vida de las mujeres para con sus difuntos consistía en ir a visitar las tumbas a lo largo de toda su vida, encargándose del cuidado, del adorno y del arreglo de las mismas. Las libaciones eran una parte muy importante de las mismas, consistían en filtraciones a la tierra de aceite, miel, vino,... que también ejecutaban las mujeres, lo que remarcaba, de nuevo, su carácter nutricio.

En el más allá la cultura griega no distinguió, eso sí, entre hombres y mujeres, ambos eran iguales en ese último viaje ${ }^{53}$. Es decir, la situación en el más allá equiparaba a hombres y mujeres, algo que, como venimos viendo, no sucedía entre los vivos. Pero incluso los propios funerales daban la posibilidad a las mujeres de ejercer un tipo de

\footnotetext{
${ }^{52}$ Ver N. Loraux (2004 a).

${ }^{53}$ Y la justificación nos la proporciona de nuevo M. D. Molas Font, que señala como “... la explicación radica en el hecho de que, por lo menos hasta la época clásica, el imaginario griego no recreó el más allá según el modelo patriarcal diseñado para el mundo terrenal, y por esta razón nada diferente se esperaba de hombres y mujeres en el mundo de los muerto ..." (Molas Font, 2003: 123).
} 
socialización que les otorgaba un cierto cambio en su vida cotidiana. Así, por ejemplo, en Atenas las mujeres, recluidas normalmente en el interior de las casas, aprovechaban este tipo de acontecimientos para mostrar sus mejores galas, incluso parece haber quedado constancia de un proceso legal que se llevó a cabo cuando la viuda de un tal Eratóstenes, durante los funerales de su esposo, encandiló a un admirador ${ }^{54}$.

\section{Los trabajos femeninos dentro del hogar}

\subsection{El tejido y el hilado: importancia económica y valor simbólico de la labor más apreciada en las mujeres}

“...En cuanto a la mujer, si instruida por el marido en el bien se porta mal, tal vez en justicia tendría ella la culpa, pero si el marido se vale de ella a pesar de su ignorancia, sin haberla educado en el camino del bien, ¿no será él el que cargue con razón con las culpas?...¿¿hay alguien a quien confíes asuntos más importantes que a tu mujer?...¿ $\mathrm{Y}$ hay alguien con quien hables menos que con tu mujer?... El dinero entra en general en la casa gracias al trabajo del hombre, pero se gasta la mayoría de las veces mediante la administración de la mujer. Si esta administración es buena la hacienda aumenta..."

Xen., oik. (oec.), III, 11-16

Comenzaremos como una frase que recoge en una de sus obras Claude Mossé, y que ilustra a la perfección acerca de las labores de las mujeres pudientes dentro del hogar, del oikos en boca de uno de los héroes míticos de los poemas de Homero y de su esposa, ejemplo de virtud y de castidad en las ausencias de su marido, “...Así se lo dice Ulises a Penélope después de su reencuentro, cuando establece los papeles respectivos

\footnotetext{
${ }^{54}$ Ver I. Jenkins (1998: 42).
} 
del esposo y de la esposa: "ahora que hemos encontrado de nuevo nuestro amado lecho, deberás cuidar de los bienes que tengo en el palacio... "55. Y es que hemos visto como el espacio de las mujeres es el ámbito privado del hogar, el oikos, y sus funciones esenciales la reproducción y los cuidados, pero no menos importantes son los trabajos domésticos que en él realiza por lo que vamos a tratar de analizar algunos de aquellos "saberes" que componían su vida diaria.

La obra de la antigüedad que nos ha legado la búsqueda de la excelencia en el cultivo de la tierra y, por tanto, en el trabajo, es Los trabajos y los días de Hesiodo. Y es llamativo porque en sus líneas apenas existen datos a partir de los cuales se pueda extraer información acerca del trabajo desempeñado por las mujeres ${ }^{56}$. Se limita a asignarles la ya analizada relación con la maternidad y su asignación al hogar como espacio propio ${ }^{57}$. Un hecho que quizá se deba a que está evitando precisamente darles un papel $^{58}$, una función, que por otra parte sin duda tenían, para negarles una condición como seres humanos, y un espacio dentro del mundo.

A pesar de ello, incuso Hesiodo hace una pequeña, y única alusión a uno de los trabajos más deseables para las mujeres, considerado el más importante, la labor textil, y lo hace cuando recomienda a los hombres el día doce del mes como el más recomendado para el esquilado de las ovejas, en el que la mujer debía tener bien dispuesto su telar para ponerse a trabajar en la lana que su marido le aportara ${ }^{59}$.

\footnotetext{
${ }^{55}$ Ver C. Mossé (2001: 30).

${ }^{56} \mathrm{Se}$ llega a considerar incluso que a partir de Hesíodo se extenderá por toda la literatura griega una fortísima corriente de misoginia que hará de la mujer la causa de todos los males (Durán López, 1996: 48-49), e incluso suponía el símbolo de la vida culta, de la fundación de la vida cívica (Olvera, 2005: 8). Para algunos el tejido incluso era tan importante como la agricultura.

${ }_{58}^{57}$ Ver M. Madrid (1999: 96).

58 "No engañe tu mente una mujer de trasero emperifollado, susurrando palabras seductoras mientras busca tu granero; quien confía en una mujer, ése confía en los ladrones..." (Hes., Trab. Y Días, 374-375).

${ }^{59}$ Ver Hes. (Trab. y Días, 770-781).
} 
No obstante, en la obra que es fiel reflejo de la sociedad aristocrática y mítica en Grecia, la Ilíada de Homero ${ }^{60}$, son muchos los momentos en que se nos describe a las mujeres practicando estas las labores. El autor utiliza el acto de tejer de las esposas de los héroes como contrapunto al combatir de ellos; así Helena está tejiendo en su cuarto, mientras los troyanos y los aqueos están en lucha por ella en el campo de batalla; la misma tarea que realiza Andrómaca cuando su esposo Héctor se enfrenta a Aquiles ${ }^{61}$. Dos actividades que el autor hace paralelas, asemejando la resistencia de los aqueos, y lo equilibrado de la lucha de ambos bandos, con la balanza en que la mujer pesa la lana; o describiendo la manera de competir en una carrera, en comparación con los movimientos que una mujer realiza en el telar; o empleando el verbo hyphaíno ("tejer") para referirse al modo en que los varones tejen en público sus discursos ${ }^{62}$.

Y a este respecto hay que hacer una alusión a la divinidad que ejerce como protectora de ambas labores, la de la guerra hoplita y la de las labores del tejido y el hilado, que resulta ser es la misma, la diosa Atenea ${ }^{63}$. Una deidad femenina, pero con unas atribuciones muy particulares, dado que ella es hija por partenogénesis, tras la

${ }^{60}$ Una obra que se caracteriza por la exaltación de los valores heroicos y una desatención al trabajo productivo, puesto que no era una de las cualidades que se apreciaba entre la aristocracia, así la fuerza y el valor eran atributos masculinos, mientras el amor al trabajo era propio de las mujeres, (Mirón Pérez, 2001: 7), que en cambio no era esencial entre sus compañeros (Mirón Pérez, 2001: 13).

${ }^{61}$ Vemos pues que no se trata de una labor exclusiva de esposas y amas de casa ideales, pues la adúltera Helena no es el mejor ejemplo de castidad, pero más significativo aún es que la maga Circe o la ninfa Calipso también aparezcan en Homero junto al telar, pues las mujeres, por poderosas o independientes que sean, mortales o inmortales, son ante todo mujeres, y como tales se dedican a esta empresa de la lana (Mirón Pérez, 1999: 218).

${ }^{62}$ Ver M. Madrid (1999: 44). En relación a ello hay que tener en cuenta las palabras de M. D. Mirón que señala el hecho de que hay tres palabras griegas, en cuanto a la equiparación de lenguajes masculinos y femeninas, que comparten la misma raíz: lana (eiros), hablar y reunirse (eiro) y paz (eirene), que aunque no tengan una conexión etimológica clara sí nos ilustran una cierta relación conceptual (Mirón Pérez, 2004: 255).

${ }^{63}$ Ver M. D. Mirón Pérez (2004: 251). Dos papeles que claramente se contraponen, pero que a la vez de alguna forma se complementan, y es que en la Grecia antigua la división de papeles de género asigna la guerra a los varones (una función destructiva), excluyendo a las mujeres de la misma, que son a su vez encargadas de la reproducción (un papel constructivo) (Mirón Pérez, 2002: 63). 
ingesta de Metis ${ }^{64}$, lo que la vincula también con un cierto componente masculino, de hecho es una de las diosas vírgenes del panteón heleno.

Pero a pesar de las peculiaridades descritas, no es la única diosa en relación al tejido, puesto que también Hestia, divinidad del hogar, de algún modo estaba vinculada a él, dado que la palabra histia designaba en Grecia tanto al altar del hogar como a la mujer que teje, y el vocablo histos se refería tanto al mástil del barco como al del telar ${ }^{65}$. Lo que de nuevo nos habla de la versatilidad del tejido como metáfora de un concepto mucho más amplio de trabajo y de función dentro la polis, aunque se desempeñara en el seno del hogar, del sexo femenino. Algo que nos muestra cómo el tejido garantiza la unidad política, la preservación de la polis y la integración social.

También en la mitología las Horas, que definen las estaciones y los ciclos agrícolas, son hermanas de las Moiras, que tejen el destino de los humanos, y ambas se complementan en una nueva metáfora del destino de los humanos que se hila en el tiempo $^{66}$, lo que nos une de nuevo un trabajo desempeñado por los varones con el desempeño de las tareas del tejido de las mujeres.

El trabajo de la lana en el mundo griego es uno de los símbolos fundamentales de la feminidad, por ello comenzaremos por éste ${ }^{67}$. El paradigma de este hecho es Penélope, quien se pasa los días tejiendo una telar, noble tarea para un fin aún más magnánimo, dado que la labor se llevaba a cabo durante el día para ser deshecha durante la noche, y así hacer tiempo hasta la vuelta de su añorado esposo Ulises.

\footnotetext{
${ }^{64}$ Según nos cuenta Ana Iriarte lo hace ante la recomendación de Gea, para que el fruto de esa unión no le pueda disputar el poder (Iriarte Goñi, 2002: 35).

${ }^{65}$ Ver M. D. Mirón Pérez (2004: 254).

${ }^{66}$ Ver M. D. Mirón Pérez (2001: 36-37).

${ }^{67}$ Sobre la plasmación iconográfica de dicho trabajo en las producciones griegas ver F. Lissarrague (1991: 227-230), quien nos enumera una relación en la que destacan: un lecito de Amasis en que aparecen nueve mujeres trabajando la lana, donde se yuxtaponen los temas del tejido, el matrimonio y la danza, en una asimilación clara de los momentos esenciales de la actividad femenina y del tejido; o la copa de Berlín que representa a dos mujeres trabajando la lana, con un cesto a sus pies, y donde la equiparación se hace entre los hombres que beben celebrando un banquete que aparecen en su exterior, y la labor de estas mujeres, ejemplificando la organización por sexos del mundo interior y el exterior, las labores de cada cual.
} 
El trabajo textil era uno de los pilares de la economía griega, así como una de las mayores aportaciones de las mujeres a la economía familiar ${ }^{68}$, y tanto libres como esclavas eran valoradas en gran medida tanto por su belleza como por sus habilidades en el trabajo de la lana ${ }^{69}$. Esta capacidad de las mujeres aparece como algo propio, no en vano la primera mujer, Pandora ${ }^{70}$, fue beneficiada con este "don" por los dioses, cuando Zeus dio órdenes a Atenea para que le enseñase sus obras, es decir, a tejer la tela trabajada con mucho arte ${ }^{71}$. Por lo que dicha habilidad fue un atributo concedido a las mujeres por la divinidad ${ }^{72}$.

Podemos afirmar que la elaboración de los vestidos y las ropas del hogar eran uno de los trabajos fundamentales en la economía doméstica. Y hasta que en el siglo IV a.C. comenzaron a crearse manufacturas textiles con obreros de ambos $\operatorname{sexos}^{73}$, en Grecia toda la ropa se elaboraba en casa.

La labor propiamente dicha era larga y compleja. La materia principal era la lana, y lo ideal era que ésta procediera de las ovejas del propio oikos ${ }^{74}$. Una vez esquiladas el producto se lavaba con agua caliente y se dejaba secar al sol, lo que era ya

68 “...Les "erga gynaikôn”, les travaux de femmes, ce sont souvent les vêtements...”, (Brulé, 2001: 221). Por desgracia, prácticamente no ha sobrevivido casi ninguna muestra de aquellas exquisitas telas griegas, pues el clima mediterráneo no resulta apropiado para su preservación como ocurre en otros lugares como Egipto con sus papiros (Jenkins, 1998: 19). Ver M. D. Mirón Pérez (2001: 18).

${ }^{69}$ Ver M. D. Mirón Pérez (2004: 251). Parece que las niñas eran introducidas en estas labores desde muy temprano, y que las mujeres de cualquier categoría libre, jóvenes, adultas, esclavas,... disponían de este conocimiento (Brulé, 2001: 221). Ver M.D. Mirón Pérez (2001, 9).

${ }^{70}$ Sobre el Mito de Pandora ver Hes. (Trab., 42-105); Pandora es más que un mito, el origen de esa maldición para los hombres que es la raza de las mujeres, ella es la madre de las mujeres (Loraux, 1990: 76-78).

${ }^{71}$ Ver Hes. (Trab., 63-64). Es esta primera mujer el mejor reflejo de la incomprensibilidad y de la impotencia humana que existía entre los antiguos griegos para buscar, la responsable de todas las calamidades que aquejan a los seres humano, esto es, la mujer (Molas Font, 2003: 125).

${ }^{72}$ Ver M. D. Mirón Pérez (1999: 218). Matizando, no obstante, que había diferencias entre unas y otras, pues si bien el proceso del hilado y el cardado afectaba a todas las mujeres, los telares eran ante todo asunto de las señoras de la casa (Mirón Pérez, 2007: 273). Era la señora la que repartía las tareas entre el resto de las mujeres de la familia y de las esclavas.

${ }^{73}$ La crisis que se produjo en este siglo obligó a muchas mujeres a vender en el mercado sus productos textiles, e incluso a emplearse como asalariadas en estas manufacturas (Mirón Pérez, 2007: 274).

${ }^{74}$ Ver I. Jenkins (1998: 20). 
una labor femenina ${ }^{75}$. Después venía el cardado, donde la lana era estirada y peinada sobre la pierna desnuda o sobre la rodilla, las fibras resultantes eran depositadas en una cesta de esparto.

Para el hilado se usaba la rueca y el huso, un bastón rematado en su extremo superior con un gancho y en el inferior con una tortera. La lana cardada era enrollada en una rueca, que la hilandera tomaba en su mano izquierda, mientras que con la derecha tiraba de la hebra humedecida, la sujetaba en el gancho y la retorcía con los dedos haciendo girar el huso, al que enrollaba la fibra ya hilada. Es probable que al menos hubiera un telar en cada casa griega ${ }^{76}$.

Un trabajo monótono que ocupaba la mayor parte de las horas de las mujeres ${ }^{77}$, a pesar de que su ligereza y sencillez hacía posible que las labores se llevaran a cualquier parte, por lo que era compartido con otras tareas que la mujer tenía que efectuar, como el cuidado de $\operatorname{los}$ niños $^{78}$. Ya hemos visto que esta era la labor de las mujeres por excelencia, hasta el punto que definía al sexo femenino ${ }^{79}$, pero aún así el aprovisionamiento debía provenir de fuera de la casa, lo que la hace una labor de algún modo dependiente de los varones.

Sobre el proceso del trabajo de la lana tenemos las valiosas palabras que Lisístrata nos legó en la obra homónima de Aristófanes; en ella encontramos una explicación de dicho proceso entremezclada con la relación de los asuntos políticos de los varones con estas labores que las mujeres realizaban en su hogar:

\footnotetext{
${ }^{75}$ Ver M. D. Mirón Pérez (2007: 272).

${ }^{76}$ Sobre la construcción y funcionamiento de los telares griegos ver (Mirón Pérez, 2007: 273). Este proceso se basa en el sistema elemental de una serie de hilos, la trama y la urdimbre, que se entrecruzan en ángulo recto (Jenkins, 1998: 21).

${ }^{77}$ Mientras los hombres solían tener la tarde libre, como ocurre en el caso de Iscómaco según relata Jenofonte, y podía dedicar su tiempo a estar con sus amigos, las mujeres no tenían más ocupación y preocupación que su casa y su esposos, todo el día atareadas y sin tiempo para descansar (Mirón Pérez, 2001: 15).

${ }^{78}$ Ver M. D. Mirón Pérez (2001: 19).

${ }^{79}$ Hasta el punto de que cuando se producía la confiscación de los bienes de un hombre, si éste estaba casado los instrumentos de la lana eran enajenables y pertenecían a la esposa, quien seguramente los traía en el momento de casarse (Mirón Pérez, 2007: 273).
} 
“Ante todo, como se hace con los vellones, habría que desprender de la ciudad en un baño de agua toda la porquería que tiene agarrada, quitar los nudos y eliminar a los malvados, vareándolos sobre un lecho de tablas, y a los que aún se quedan pegados y se apretujan para conseguir cargos arrancarlos con el cardador y cortarles la cabeza; cardar después en un canastillo la buena voluntad común, mezclando a todos los que la tienen sin excluir a los metecos y extranjeros que nos quieren bien y mezclar también allí a los que tienen deudas con el tesoro público y además, por Zeus, todas las ciudades que cuentan con colonos salidos de esta tierra, comprendiendo que todas ellas son para nosotros como mechones de lana esparcidos por el suelo cada cual por su lado. Y luego, cogiendo de todos ellos un hilo, reunirlos y juntarlos aquí y hacer con ellos un ovillo enorme y tejer de él un manto para el pueblo"

Aristoph., Lys., 570-580

De ellos podemos extraer información acerca de cómo se desarrollaba todo el proceso, pero también vemos algo muy importante de nuevo, y es la relación de los asuntos masculinos y femeninos, la equiparación de las labores que para la ciudad debían desempeñar hombres y mujeres. Ya hemos visto cómo Homero utiliza el verbo tejer para hablar de los discursos de los varones en público; pero es que, además, los tejidos eran expuestos en las ceremonias públicas más importantes ${ }^{80}$, así como en las

\footnotetext{
${ }^{80}$ En la procesión de las Grandes Panateneas, una celebración en honor de la diosa Atenea, las mujeres de todas las edades se afanaban en la elaboración de un peplo, bajo la supervisión de las sacerdotisas, que luego le ofrecían a la esta divinidad poliada de Atenas, una realización ritual de un trabajo eminentemente doméstico que suponía un importante servicio público a la ciudad (Mirón Pérez, 2004: 256-257). Ver también en P. Brulé (2001: 222-223). Y éste no es el único ejemplo, pues en otros punto de Grecia el tejido de las mujeres de los mantos de la divinidad se dio con frecuencia, tal es el caso del manto de Hera en Olimpia, a cargo del Colegio de las Dieciséis Mujeres (Mirón Pérez, 2004: 260-262); ver M. D. Mirón Pérez (2002: 61-62); y el chitón que es cosido para Apolo en las Jacintas de Esparta (Olvera, 2005: 8). Se cree que la elaboración de un pelplo podía implicar a más de dos mujeres en un tiempo de unos nueve meses de trabajo diarias (Mirón Pérez, 2001: 18).
} 
habitaciones más nobles de la casa, donde los visitantes masculinos se reunían ${ }^{81}$; o cubrían los cuerpos de los ciudadanos cuando acudían al ágora ${ }^{82}$.

\subsection{Las labores de administración de la señora del oikos: gobernar la casa y dirigir a las sirvientas y esclavas}

“...otras actividades de tu incumbencia te resultarán más agradables: por ejemplo, cuando te hagas cargo de una esclava que no sepa hilar, la instruyas y dobles el valor que tiene para ti; o cuando te encargues de otra que no sepa administrar ni servir y la conviertas en una criada capaz, leal y eficiente, de una valor inapreciable; o cuando puedas recompensar a los servidores buenos y provechosos para tu hacienda y castigar, en cambio, a los que te resulten malos..."

Xen., oik. (oec.), VII, 41-42

Otra de las tareas esenciales en el interior del hogar era la transformación de los alimentos, los cuales eran también aportados por el trabajo en el campo de los varones, pero cuyo tratamiento era otra de las labores femeninas. El cultivo del trigo era muy importante, puesto que el pan constituía un importante alimento de la dieta de los griegos, y la elaboración de éste estuvo en manos de mujeres.

\footnotetext{
${ }^{81}$ Ver en M. D. Mirón Pérez (2004: 252). Las fuentes nos relatan como Alejandro Magno tras la batalla de Gaugamela, a finales del 331 a.C., había decidido agasajar a la reina persa Sisigambis con ropas macedonias y con tejidos púrpuras, enviándole además a las mujeres que las habían elaborado para que así pudiera enseñar estas artes a sus nietas. Pero lejos de alegrase no había peor desgracia para una mujer persa que el trabajo de la lana, por lo que Alejandro tuvo que disculparse porque las costumbres helenas provocaron el terrible error, dado que señala que sus ropas no son sólo fruto del regalo de sus propias hermanas, sino su labor (Mirón Pérez, María Dolores, 1999: 214). Ello da fiel muestra del valor que este trabajo tenía para todos los griegos.

${ }^{82}$ Hemos visto, así mismo, la relación de las copas y vasos griegos donde la mujer aparece trabajando la lana, mientras los hombres beben en banquetes (Lissarrague, 1991: 227-230). Sobre las formas de estas vestimentas consultar I. Jenkins (1998: 23-29).
} 
El grano era molido por las mujeres, que empleaban un molino de mano, pero también se empleaba el mortero. La harina era colocada en un cedazo o harnero para separar el polvo fino de los fragmentos más gruesos. Y la harina resultante era amasada con las manos en una artesa para luego proceder a cocer en pan en un horno de leña ${ }^{83}$.

No obstante, también en este trabajo había una estratificación, pues si bien el ama de casa era la que se encargaba de la buena conservación del grano, la elaboración del pan corría a cargo siempre de manos de las sirvientas ${ }^{84}$.

Y es que aquí entramos en la que era la labor básica de la señora, la organización de la casa, puesto que ella era la custodia de los bienes que dentro se guardaban. Y dirigir el trabajo de la servidumbre era una de las más importantes actividades domésticas que debía realizar una mujer. Unas sirvientas que estaban destinadas a los trabajos domésticos, pero también podían ser llamadas para compartir el lecho con el señor o con los huéspedes de la casa. Muchas de ellas eran cautivas conquistadas en las guerras o raptadas, e incluso algunas eran regalos que los nobles se hacían entre sí.

La señora debía enseñarles a hilar la lana, a tejer los paños que debían de servir posteriormente a las personas de la casa, a amasar el pan, a doblar y guardar las ropas, y a mantener la casa en orden ${ }^{85}$. Otras de las labores de estas mujeres eran: preparar la

\footnotetext{
${ }^{83}$ Ver M. D. Mirón Pérez (2007: 274). No obstante, parece que también a partir del siglo V a.C. se creó un comercio, tanto en Atenas como en otras ciudades, y empezaron a aparecer las panaderas, que incluso podían tener sus propios hornos y tiendas públicos.

${ }^{84}$ Es decir, era un trabajo femenino, pero que realizaban las mujeres de condición más humilde. No obstante, no se nos dice mucho de la gran cantidad de sirvientas que poseía cada casa, pero solían aparecer casi siempre de manera anónima a la sombra de la dueña de la casa (Mossé, 2001: $34)$.

${ }^{85}$ A pesar de que Jenofonte considera el humedecer y amasar la harina como una de las labores más apropiadas para el ama de casa (Mirón Pérez, 2007: 275).
} 

administradora

lana para su señora, preparar la rueca, traer agua para bañar a los huéspedes o para lavar las manos a los hombres de la casa, preparar los lechos ${ }^{86}, \ldots$

Dentro de los trabajos que tenían que hacer las sirvientas, el que contaba con una mayor estima puesto que requería de una mayor confianza hacia su trabajo, era el de despensera $^{87}$, que tenía a su cargo la provisión de víveres, así como es muy posible que se ocupara de las tareas culinarias y de servir la mesa ${ }^{88}$. En principio esta puede haber sido una ocupación de la señora, pero las más pudientes sin duda contaban con una servicial trabajadora para tal efecto que, controlada siempre de cerca por su ama, era la garante de las llaves de la despensa. Por lo tanto, la conservación de los alimentos era una tarea femenina ${ }^{89}$.

La nodriza era también una servidora con un papel muy importante ${ }^{90}$. Parece que debido a las implicaciones económicas que tenía la lactancia, puesto que era básica para la alimentación del niño durante los primeros años, lo ideal era que ésta la efectuara la madre, pero no era infrecuente que se recurriera a la labor de la nodriza, que

\footnotetext{
${ }^{86}$ La atención de los visitantes extranjeros para hacer que se sintieran bien en su hogar, o el baño de los huéspedes (como hace Policasta, hija de Néstor, con Telémaco, o el que le proporciona Areté a Ulises cuando abandona la isla de los feacios), es según la literatura homérica otra de las labores de la señora (Mossé, 2001: 31); ver M. D. Mirón Pérez (2007: 276). No sabemos con seguridad si esto era o no así, pero tal vez era un intento más de rebajar la categoría de las mujeres de la casa el atribuirles a las señoras del oikos las labores que llevaban a cabo las sirvientas.

87 “...Al ama de llaves la nombramos después de haber examinado con detenimiento qué esclava nos parecí más moderada en la comida, en la bebida, en el sueño y en el trato con los hombres; que además nos pareció tener mejor memoria, ser más cuidadosa...y más celosa en darnos gusto...También la educamos para que se interesara en aumentar la hacienda, haciéndola colaboradora en las decisiones y participe en los éxitos..." (Xen., oik. (oec.), IX, 11-13), lo cual nos informa de la cercanía de esta trabajadora a sus señores.

${ }^{88}$ Sobre la cocina y la alimentación de los griegos ver M. J. García Soler (2004). En la comedia casi siempre la sirvienta es la que prepara la comida, aunque en las casa importantes parece que se recurría a un cocinero para tales actividades (Mossé, 2001: 88); una figura que aparece sobre todo a partir del s. IV a.C. (Mirón Pérez, 2007: 276).

${ }^{89}$ Ver M. D. Mirón Pérez (2007: 275).

${ }^{90}$ Ver en relación a las nodrizas y las sirvientas en la literatura griega en I. Calero Secall (1999). Parece que una vez los niños se hacían mayores de sus vigilancia pasaban a ocuparse las esclavas de la casa (Mossé, 2001: 88).
} 
podía ser tanto una esclava de la casa como una mujer que trabajaba a cambio de un sueldo, que alquilaba su cuerpo, para el sustento del recién nacido ${ }^{91}$.

Por último, las servidoras más humildes eran las esclavas. Mientras que los esclavos podían ejercer diferentes actividades (forense, policía, campesino, obrero, marinero,...), las mujeres de esta condición sólo podían aspirar a un empleo doméstico, y vivían en un estado de sumisión a la dueña de la casa. Normalmente su trabajo consistía en hacerse cargo de las tareas de la cocina y dedicarse a la fabricación de paños $^{92}$, así como se ocupaban de la limpieza de la casa y de las cosas que ésta contenía ${ }^{93}$.

Parece que estas mujeres no tenían vida familiar alguna, y se exigía que hombres y mujeres estuviesen separados en sus dormitorios para evitar que las esclavas tuvieran hijos sin el permiso de sus dueños, la mayoría de las veces estas mujeres tenían hijos fruto de las relaciones a las que la sometía el señor de la casa. Y tal era su dependencia que su destino estaba en manos de la buena voluntad de su amo, pues sólo su decisión y su gratitud podían devolverles la libertad.

\section{Conclusiones acerca de las labores de las mujeres griegas en el ámbito doméstico}

En el presente trabajo hemos intentado poner de manifiesto la situación concreta de las mujeres dentro del que era su lugar concreto de trabajo, allí donde se producía no sólo el desenvolvimiento de la mayor parte de su vida, sino donde van a realizar las principales ocupaciones para las que estaban destinadas según el modelo social de la Grecia Antigua.

A través de las fuentes escritas y de los materiales arqueológicos hemos tratado de recomponer los misterios que se escondían para ellas tras los muros del hogar, así

\footnotetext{
${ }^{91}$ Ver M. D. Mirón Pérez (2007: 276).

${ }^{92}$ Ver C. Mossé (2001: 90).

${ }^{93}$ Ver M. D. Mirón Pérez (2007: 276).
} 
como los peligros y los diferentes pasos por los que debían pasar desde su fase como infantes a su culminación como madres y esposas, viendo cómo en definitiva los papeles se perpetuaban de madres a hijas, de abuelas a madres,... en una vida diaria que poco difería de unos estadios a otros. La ateniense de buena familia se quedaba en casa, rodeada de sus criadas, a quienes debía controlar y enseñar, y sólo salía para cumplir con sus deberes religiosos ${ }^{94}$.

En el seno del hogar, su función consistía en asegurar al esposo la transmisión del patrimonio a través de su función como engendradora de su progenie legítima, así como la correcta gestión de los asuntos domésticos y de todo el servicio que estaba bajo el techo sobre el que el varón correspondiente ejercía su influencia. Y donde destacaba sobre cualquiera de sus labores el tejido, no tanto por el valor de su trabajo o por la aportación al sustento material de la casa, sino porque se ensalza con esta labor la virtud femenina por excelencia, la calidad de ergastis, de laboriosa, tal como vimos que fuera el ideal que conformaba la virtuosa Penélope ${ }^{95}$.

Para lo cual se consagra a una serie de actividades muy concretas y muy estereotipadas que se van a reproducir una y otra vez en las casas más humildes y en las más ricas (con la salvedad ya vista de que las mujeres más pobres veían acrecentada una cierta libertad al estar obligadas a buscar un sustento económico fuera del hogar para poder aportar una ayuda que permitiera la subsistencia familiar, lo que les permitía al menos salir de los muros de sus casas ${ }^{96}$ ).

Las aristocráticas tenían pues otras mujeres que, en mayor o menor medida, convivían con ella realizando funciones muy diversas: desde las concubinas y hetairas con las que en ocasiones su esposo la obligaba a convivir, encargadas de los "trabajos" del cuerpo; hasta las sirvientas y nodrizas que le apoyaban en los quehaceres del día a

\footnotetext{
${ }^{94}$ No hay que olvidar que frente a estas mujeres de la aristocracia habría un gran número de féminas humildes se verían obligadas a salir de su casa para ir al mercado, incluso para aumentar los recursos familiares que tendrían algunas con sus escasos salarios de nodrizas (Mossé, 2001: 67). Sobre la mujer y su religiosidad dentro de la polis ver L. Bruit Zaidman (1991); y R. M. Olvera (2005: 5-8).

${ }^{95}$ Ver F. Lissarrague (1991: 227)

${ }^{96}$ Ver C. Mossé (2001: 67).
} 
día. Y, en este sentido, me refiero a que si bien entre los hombres se daban notables diferencias, la señora de la casa vivían más cerca de sus sirvientas que de las mujeres que eran como ella, y por supuesto que de su marido, lo que sin duda generaba estrechos lazos entre estas mujeres del oikos que las equiparaba en su condición social ${ }^{97}$.

Pero la ocupación fundamental de las mujeres, su trabajo más reconocido, aquel por el que podían convertirse en mujeres virtuosas, se repetía una y otra vez, en todos los ámbitos en que desempeñaba su aportación a la economía, ella era fundamental mente una cuidadora ${ }^{98}$ de la casa y de sus habitantes (su esposo, sus hijos, sus sirvientas, sus esclavos, los enfermos, las gentes de mayor edad, la administración de la casa,...). Ese era su verdadero papel, para lo que estaba preparándose toda su vida.

Por tanto, los trabajos desempeñados por mujeres se realizaban fundamentalmente, como hemos visto, dentro del hogar y eran tan importantes como los de la producción de objetos que llevaban a cabo sus compañeros, además en el mundo griego ambas labores se consideraban parte de la "economía"

En cuanto a la valoración social de este trabajo, su apreciación era muy escasa, salvo en su capacidad como reproductora, que la convertía en mantenedora de la vida en la polis, si bien es cierto que se concedía muy poco valor a la participación femenina en el proceso de creación de nuevos individuos, como hemos visto. En cambio trabajos como el textil suponían una fuente de ingresos importante para algunas familias, sobretodo las no privilegiadas, y el hecho de que una esclava o sirvienta tuviera estas habilidades con la lana aumentaba su valor particular ${ }^{100}$. Aunque lo que nunca varió fue la consideración de ser más rentables las labores llevadas a cabo en el exterior, es decir, aquellas que eran competencia de los varones.

\footnotetext{
${ }^{97}$ Todas ellas configuran esa génos gynaikôn (Loraux, 1990: 76).

${ }^{98}$ Ver M. D. Mirón Pérez (2007: 276).

${ }^{99}$ Ver M. D. Mirón Pérez (2007: 276).

${ }^{100}$ Ver M. D. Mirón Pérez (2007: 277).
} 
Se ha llegado a considerar incluso que la mujer trabajadora era sexualmente más atractiva en la Grecia antigua ${ }^{101}$, y se equiparaba la habilidad de la producción de objetos con la capacidad para reproducir nuevos individuos; por consiguiente, se relacionaban producción y reproducción.

Por tanto, el trabajo femenino, reconocido o no, dentro del ámbito doméstico era muy importante, y la mejor prueba de ello es que un historiador y filósofo de la Grecia del siglo IV a.C. como fue Jenofonte, dedicó una buena parte de su obra "Económico"l02 a abogar por la importancia de una buena preparación (que corría a cargo no sólo de los padres, sino una vez casada del esposo) y por el cuidado y los “derechos" de las mujeres como hemos visto anteriormente, puesto que considera decisiva su importancia en el correcto mantenimiento del hogar ${ }^{103}$. Y es precisamente en su definición de la oikonomía donde encontramos la justificación más categórica de la importancia del trabajo femenino en el hogar, ya que para él era la ciencia que hacía que los hombres pudieran acrecentar su oikos, tanto sus elementos humanos como materiales $^{104}$; y en ese crecimiento la labor de las mujeres era tanto o más importante, productiva y reproductivamente, que la de los hombres.

Y una última apreciación para concluir este trabajo, hay que señalar que el término que se utilizaba en Grecia para definir el saber es sophia, una palabra que no estaba cargado de las implicaciones actuales de conocimiento de datos, de saber cosas, sino que su acepción era "saber vivir", saber estar y saber actuar adecuadamente. Y esto es muy ilustrador, puesto que si bien tal vez el trabajo femenino, su peculiar saber, no era del todo estimado en la sociedad griega, o al menos no en tanta medida como el masculino, sí era una labor que contaba con un buen empleo de la sophia, puesto que

\footnotetext{
${ }^{101}$ La belleza física se corresponde con la sophrosyne, la ausencia de vicios y la capacidad de controlar las pasiones, (Mirón Pérez, 2001: 9).

${ }^{102}$ Ver Xen. (oik. (oec.), VII-X).

103 Jenofonte pone en boca de Iscómaco las siguientes palabras: “...Nunca paso el día entero en mi casa, pues mi mujer se basta por sí sola para administrarla...” (Xen., oik. (oec.), VII, 3-4). Y es que para Jenofonte la mujer será la gobernadora de la casa y la madre de los hijos del marido (Brulé, 2001: 193).

${ }^{104}$ Ver M. D. Mirón Pérez (2007: 278-279).
} 
ellas sin duda realizaban sus funciones con tal maestría que generación tras generación fueron las encargadas del sustento y del correcto funcionamiento del oikos. Y ésta es, sin lugar a dudas, la mejor prueba de su buen hacer, de sus cualidades y de la necesidad que la sociedad tenía de ellas.

Como señala Pierre Brulè en relación a unas palabras que Jenofonte pone en boca de uno de sus personajes, la mujer en Grecia se encargaba de gobernar, administrar, regentar, regular, dirigir, educar y alimentar en la casa ${ }^{105}$, esas eran sus actividades y ese era el sentido del verbo que emplea el autor, dioikein, el esposo no se ocupaba de nada en el interior de su hogar, puesto que ya su esposa se encarga de hacerlo con total capacidad. Así que poco era el valor que se le concedía a este trabajo $^{106}$, pero en realidad parece que ya los propios griegos lo consideraban como imprescindible para el sustento no sólo de la casa, sino de la vida familiar. Tal como nos lo manifiesta Jenofonte de nuevo en boca de Iscómaco y de su esposa:

“...Mi mujer me respondió: "Mucho me sorprendería a ti más que a mí las funciones de jefe, pues mi vigilancia y mi administración de los asuntos domésticos parecerían ridículos, en mi opinión si tú no te cuidaras de aportar algo de fuera". "Y a su vez, contesté, "Mi aportación sería ridícula si no hubiera quien conservara lo que se almacena dentro..."

Xen., oik. (oec.), VII, 39-40

\footnotetext{
${ }^{105}$ Ver P. Brulé (2001: 206).

${ }^{106}$ Dice el propio autor que "...la femme travaille, mais c'est, d'une certaine façon, un travail qui ne compte pas. Ni aux yeux des pères ni à ceux des maris...” (Brulé, 2001: 217).
} 


\section{BIBLIOGRAFÍA}

- Almirall Arnal, E. (2002): "La religiosidad femenina en la Ilíada y en la Odisea". En M. D. Molas Font: Vivir en femenino. Estudios de mujeres en la antigüedad. Barcelona: Universitat de Barcelona, pp.113-122.

- Bermejo Barrera, J. C. (1996 a): “Deméter: alimentación, ley y matrimonio en la religión griega arcaica”. En J. C. Bermejo Barrera, F. J. González García y S. Reboreda Morillo: Los orígenes de la mitología griega. Madrid: Akal, pp. 95-113.

- Bermejo Barrera, J. C. (1996 b): “Zeus, Hera y el matrimonio sagrado”. En J. C. Bermejo Barrera, F. J. González García y S. Reboreda Morillo: Los orígenes de la mitología griega. Madrid: Akal, pp. 75-93.

- Bermejo Barrera, J. C. (1996 c): “Zeus, sus mujeres y el reino de los cielos”. En J. C. Bermejo Barrera, F. J. González García y S. Reboreda Morillo: Los orígenes de la mitología griega. Madrid: Akal, pp. 41-74.

- Bruit Zaidman, L. (1991): "Las hijas de Pandora. Mujeres y rituales en las ciudades". En G. Duby y M. Perrot (dir.): Historia de las Mujeres. La Antigüedad, Vol. I. Madrid: Altea, pp. 372-419.

- Brulé, P. (2001): Les femmes grecques à l'époque classique. París: Hachette Littératures.

- Calame, C. (2002): Eros en la Antigua Grecia. Madrid: Akal.

- Calero Secall, I. (1999): Consejeras, confidentes, cómplices: la servidumbre femenina en la literatura griega antigua. Madrid: Clásicas.

- Calero Secall, I., Alfaro Bech, V. (2005): Las hijas de Pandora: Historia, Tradición y Simbología. Málaga: Atenea.

- Cantarella, E. (1991): Según Natura: la bisexualidad en el mundo antiguo. Madrid: Akal.

- Cantarella, E. (1990): “ Donne di casa e donne sole in Grecia: sedotte e seduttrici”. En A. López, C. Martínez y A. Pociña (eds.): La mujer en el mundo Mediterráneo antiguo”. Granada: Feminae, pp. 35-51. 
- De La Nuez Pérez, M. E. (2004): "Las Panateneas: topografía de una fiesta". En Gerión, n 22, pp.101-120.

- Durán López, M. A. (1996): "Mujer y modalidades del saber en la Grecia Antigua". En M. I. Calero Secall y R. Francia Somalo (coords.): Saber y Vivir: Mujer, Antigüedad y Medievo. Málaga: Atenea.

- Flacelière, R. (1989): La vida cotidiana en Grecia en el siglo de Pericles. Madrid: Temas de Hoy.

- García Soler, M. J. (2004): “Alimentación y la salud en la Grecia antigua”. En Bitarte: Revista cuatrimestral de humanidades, $\mathrm{n}^{\mathrm{o}} 34$, pp. 5-20.

- Garrido González, E. (1986), La mujer en el mundo antiguo. Madrid: Universidad Autónoma de Madrid.

- González Suárez, A. (1994): “Aspasia y los Epitafios”. En E. Pérez Sedeño, (coord.): Conceptualización de lo femenino en la filosofía antigua. Madrid: Siglo XXI, pp. 45-64.

- Iriarte Goñi, A. (1990): Las redes del enigma: voces femeninas en el pensamiento griego. Madrid: Taurus.

- Iriarte Goñi, A. (1996): "Ser madre en la cuna de la democracia o el valor de la paternidad”. En S. Tubert (ed.): Figuras de la madre. Madrid: Cátedra, pp. 73-93.

- Iriarte Goñi, A. (2002): De amazonas a ciudadanos. Pretexto ginecocrático y patriarcado en la Grecia Antigua. Madrid: Akal.

- Iriarte Goñi, A. (2003): Departamento de Cultura y Euskera, Diputación Foral de Guipúzcoa. Antiqua. Jornadas sobre la Antigüedad, "La imagen del ateniense ideal", [Consultada el 12 de Diciembre de 2002], Disponible desde Internet: http://antiqua.gipuzkoakultura.net/imagen_ateniense_ideal_eu.php.

- Jenkins, I. (1998): La vida cotidiana en Grecia y Roma. Madrid: Akal.

- Leduc, C. (1991): “¿Cómo darla en matrimonio? La novia en Grecia, siglos IX-IV a.C.”. En G. Duby y M. Perrot (dir.): Historia de las Mujeres. La Antigüedad, Vol. I. Madrid: Altea, pp. 250-313.

- Lissarrague, F. (1991): “Una mirada ateniense". En G. Duby y M. Perrot (dir.): Historia de las Mujeres. La Antigüedad, Vol. I. Madrid: Altea, pp. 183-245.

- Loraux, N. (1990): Les enfants d'Athéna. Idées ateniense sur la citoyenneté et la division des sexes. París: La Decouverte. 
- Loraux, N. (1991): “¿Qué es una diosa?”. En G. Duby y M. Perrot (dir.): Historia de las Mujeres. La Antigüedad, Vol. I. Madrid: Altea, pp. 29-71.

- Loraux, N. (1993) : Grecia al femminile. Roma : Laterza.

- Loraux, N. (2004 a): Las experiencias de Tiresias (Lo masculino y lo femenino en el mundo griego). Barcelona: El Acantilado.

- Loraux, N. (2004 b): Madres en duelo. Madrid: Abada.

- Madrid, M. (1999): La misoginia en Grecia. Madrid: Cátedra.

- Mirón Pérez, M. D. (1999): "Realeza y labor doméstica en Macedonia Antigua". En Gerión, nº17, pp.213-222.

- Mirón Pérez, M. D. (2000): "Las mujeres, la tierra y los animales: naturaleza femenina y cultura política en la Grecia Antigua". En Florentia Iliberritana, nº 11, pp.151-169.

- Mirón Pérez, M. D. (2001): “Tiempo de mujeres, tiempo de hombres: género, ocio y trabajo en Grecia Antigua”. En Arenal, vol. 8, nº, pp. 5-37.

- Mirón Pérez, M. D. (2002): "Niñas y ancianas en la Antigua Olimpia: tejiendo el orden de género y la paz”. En M. Ortega López y M.P. Pérez Cantó: Las Edades de las mujeres. Madrid: Universidad Autónoma de Madrid.

- Mirón Pérez, M. D. (dir.) (2004): Las mujeres y la paz: génesis y evolución de conceptualizaciones, símbolos y prácticas. Madrid: Instituto de la Mujer.

- Mirón Pérez, M. D. (2007): “Los trabajos de las mujeres y la economía de las unidades domésticas en la Grecia Clásica”. En Complutum, nº18, pp. 271-280.

- Molas Font, M. D. (2002): “Engendrar y parir en la Ilíada y en la Odisea”. En M. D. Molas Font: Vivir en femenino. Estudios de mujeres en la antigüedad. Barcelona: Universitat de Barcelona, pp. 153-178.

- Molas Font, M. D. (2003): "Mujeres y rituales funerarios en la Grecia antigua”, en M. D. Molas Font y S. Guerra López (eds.): Morir en femenino. Mujeres, ideología y prácticas funerarias desde la Prehistoria hasta la Edad Media. Barcelona: Universitat de Barcelona, pp. 99-126.

- Mosse, C. (2001): La Mujer en la Grecia Clásica. Madrid: Nerea.

- Mosse, C. (1990): “Courtisanes et/ou femmes mariées”. En A. López, C. Martínez y A. Pociña (eds.): La mujer en el mundo Mediterráneo antiguo”. Granada: Feminae, pp. 27-34. 
- Olvera, R. M., (2005): Facultad de Ciencias Políticas y Sociales de la Universidad Nacional Autónoma de México, Revista Razón Cínica, “Eran misóginos los griegos?”, [Consultada el 19 de Junio de 2007], Disponible desde Internet:http://www.politicas.unam.mx/razoncinica/17_abril05/olvera_misog_griegos.html. - Sissa, G. (1991): “Filosofías de género: Platón, Aristóteles y la diferencia sexual”. En G. Duby y M. Perrot (dir.): Historia de las Mujeres. La Antigüedad, Vol. I. Madrid: Altea, pp. 73-113.

\section{FUENTES}

Aristófanes (1993), Lisístrata, (intr., trad. y notas Luis M. Macía Aparicio), Ed. Clásicas, Madrid.

Cornelio Nepote (1985), Vidas, (intr.., trad. y notas de Manuel Segura Moreno), Ed Gredos, Madrid.

Demóstenes (1983), Discursos privados, (intr., trad. y notas de Jose Manuel Colubi Falco), Ed. Gredos, Madrid.

Homero (2005), Himnos Homéricos, (trad. de José B. Torres), Ed. Cátedra, Madrid.

Hesiodo (2005), Teogonía, (intr., trad. y notas de Adelaida Martín Sánchez y de María Ángeles Martín Sánchez), Ed. Alianza, Madrid.

Hesiodo (2005), Los trabajos y los días, (intr., trad. y notas de Adelaida Martín Sánchez y de María Ángeles Martín Sánchez), Ed. Alianza, Madrid.

Jenofonte (1993), Económico, (intr., trad. y notas de Juan Zaragoza), Ed. Gredos, Madrid.

Sófocles (1983), Fragmentos, (intr., trad. y notas de Jose Maria Lucas de Dios), Ed. Gredos, Madrid. 